\title{
Biologic Specimen Condition Code
}

National Cancer Institute

\section{Source}

National Cancer Institute. Biologic Specimen Condition Code. NCI Thesaurus. Code C93749.

A coded value specifying the discreet list of values describing the condition of the specimen at time of receipt at the lab. 